\title{
Singleness, Marriage, and the Construction of Heterosexual Masculinities: Australian Men Teaching English in Japan
}

\author{
Roslyn Appleby, University of Technology Sydney
}

Recent scholarship has highlighted the global industry of English language education and teaching (ELT) as a site for the production of racialised, sexualised, and gendered professional identities. In Japan, white Western ${ }^{1}$ men have been identified as objects of Occidentalist desire, symbolising a romantic ideal associated with Western culture; but at the same time, white men working as English language teachers in Japan face the challenge of negotiating competing discourses that threaten their social status. A reputation for sexual promiscuity, and employment in a lowly regarded but ubiquitous occupation, potentially position Western male language teachers as the 'white trash' of Asia (interviewee cited in Farrer 2010: 84). ${ }^{2}$

This article draws on data from interviews with white Australian men and examines how they negotiate conflicting discourses of masculinity in their accounts of living and working in Japan as English language teachers. It focuses, in particular, on the

\footnotetext{
${ }^{1}$ I recognise that terms such as 'white' and 'Western' are contentious, and have been extensively analysed and problematised in critical whiteness and race studies. In line with contemporary scholarship, I see both 'whiteness' and 'Western' (and 'heterosexuality') as discursive constructions and ascribed identity markers that have significant material and structural consequences. In this paper I adopt these terms because they are the most widely used in the scholarship of English language teaching (ELT). Here, they are used to denote English language teachers who are so-called 'native speakers' of English from what is considered to be the Anglophone Centre, that is, the USA, UK, Canada, Australia or New Zealand, where English is regarded as the dominant first language. In the global English language teaching industry, 'white native speaker privilege' has been widely documented.

${ }^{2}$ The term 'white trash' and other derogatory phrases have been used to refer to the low status of nativespeaker English language teachers, and to their widespread employment—particularly in the lower echelons of the ELT industry - in countries where English is not the majority language (see Cho 2012; Lan 2011; Stanley 2012).
}

PORTAL Journal of Multidisciplinary International Studies, vol. 10, no. 1, January 2013.

Australians Abroad Special Issue, guest edited by Juliana De Nooy.

ISSN: 1449-2490; http://epress.lib.uts.edu.au/ojs/index.php/portal

PORTAL is published under the auspices of UTSePress, Sydney, Australia. 
discursive construction of marriage as a means of projecting an acceptable account of oneself as a Western male in Japan. More broadly, this study seeks to contribute to an ongoing discussion of the ways in which gender, heterosexuality, and heteronormativity are manifest in contemporary geopolitics (Bell \& Valentine 1995; Hubbard 2000; Philo 2005), at the intersection of public and private domains, and in global flows of gendered and sexualised labour (Cho 2012; Farrer 2008; Lan 2011; McDowell 2008; Robinson 2007; Stanley 2012).

\section{Occidentalist desire and English language teaching in Japan}

In recent years a contentious body of research has investigated the attraction expressed by some Japanese women for the West, for Western men, and for English language as a means of access to the West (Bailey 2006, 2007; Ichimoto 2004; Kelsky 2001; Kubota, 2011; Ma 1996; Ono \& Piper, 2004; Piller \& Takahashi 2006). According to these accounts, Japanese women's agentive desire, underpinned by a newly found economic independence and propelled by glamorous media images of Western romance, has accorded Western masculinity a privileged place in the Japanese imaginary. Japanese women's agency is said to subvert, at least partially, earlier colonial and Orientalist discourses (Said 1978) in which a dominant, masculine West is set in contrast to a submissive feminised East. The gender imbalance in marriages between Western men and Japanese women ${ }^{3}$ in recent decades (Yamamoto 2010; MHLW 2010) is, perhaps, a testament to the material consequences of these contemporary discourses and desires.

The English language teaching industry has played a fundamental role in 'creating and sustaining Occidentalist mythologies of people and place among Japanese' (Bailey 2007: 601), and Western male English language teachers stand at the intersection of the practices in which those desires are realised. However, past research on the dynamic effects of Occidentalist desire has primarily attended to the experiences of Japanese women, and little is known about the embodied responses of male teachers in this context. Some insights can be garnered from Bailey's discussion of his experiences as a white, male English-speaking language instructor and ethnographic researcher in several Japanese eikaiwa gakkô (English language conversation schools). According to Bailey,

\footnotetext{
${ }^{3}$ Marriages between Japanese and non-Japanese show marked patterns of gender and ethnicity. In 2009, for example, 89 percent of Japanese and North Americans were between a Japanese bride and an American groom (MHLW 2010).
} 
conversation schools enrol a majority of female students, ${ }^{4}$ and tend to favour employment of young white male teachers as a 'key selling point' (Seargeant 2009: 96; Piller \& Takahashi 2006; Kubota 2011). In this eroticised space, 'male gaijin [foreign] instructors were often elevated to movie icon status' (Bailey 2007: 598) and 'crosscultural romantic / sexual / marital partnership ... was normalized by students, staff and other instructors' (600). In a similarly personal reflection on his experience as an American English teacher in Japan, Kelly (2008: 268) recalls that 'it was pleasant to have status, money, and popularity merely on the basis of being white' and notes that 'for Western men, the availability of Japanese women has been a big attraction.'

Apart from these brief insights, in scholarly literature there is relative silence on men's responses to these dynamics. Perhaps a clue to this silence can be found in Western men's reluctance to situate themselves in relation to two damaging discourses that are associated with the eikaiwa industry and threaten to devalue the teachers' personal and professional standing. First is the lowly status ascribed to English language teaching as an occupation readily available to 'native speakers' of English, who may have a bachelor's degree of some kind in any discipline, but in most cases are not required to have teaching qualifications or experience. ${ }^{5}$ The second problematic discourse, dating back to colonial times and notions of Orientalist, Euro-masculine potency, concerns Western men's historical and discursive reputation for the sexual pursuit and exploitation of Asian women (Kubota 2008; Ling 1999; Stoler 1995). Negotiating this discourse may be particularly problematic for male teachers, since the spectre of embodied heterosexual desire sits uncomfortably with principles of pedagogical propriety (Valentine 1997) and ideals of 'selfless, sexless nurturance' that define the role of the 'good teacher' (Gallop 1995: 83).

Given these conflicting discourses, it seems that male English language teachers in Asia occupy an awkward space that is shaped, in part, by their positioning and performance as heterosexual men. My questions, then, concern how the white Australian men in my study mobilise and manage a range of competing heterosexual identities, and how those

\footnotetext{
${ }^{4}$ While accurate enrolment data for commercial eikaiwa schools are not publicly accessible, several studies have noted the predominance of women as students, and as the target of eikaiwa gakkô marketing (see, for example, Piller \& Takahashi 2006). Research also suggests that this pattern of female enrolment in English language learning is repeated in tertiary institutions in Japan, and in study abroad programs (see, for example, Ichimoto, 2004; Kobayashi, 2002).

${ }^{5}$ See recruitment information on the websites of major eikaiwa gakkô.
} 
identities produce distinctions and boundaries - between body and mind, self and other, home and abroad - across a geography that links individuals to institutional places, practices and privileges. I have written elsewhere about the opportunities and challenges these men face during their employment in the eikaiwa industry (Appleby 2012). In the present article, I focus more specifically on how they use normative constructions of marriage to map 'the moral contours of heterosexuality' (Hubbard 2000: 191) and to distance themselves from unpalatable stereotypes.

\section{Male English language teachers in popular culture}

The ambiguous position of white Western men in Japan has featured in popular culture, particularly in the notorious comic strip character of 'Charisma Man' (Rodney \& Garscadden 2002, 2010; see also the Charisma Man website 2013). ${ }^{6}$ Charisma Man is a skinny, chinless weakling who finds himself transformed into a handsome, muscular 'superhero'-at least in the eyes of adoring Japanese women - when he arrives in Japan. In the comic strip series, Japanese women are doting sexual partners for Charisma Man, and his arduous employment as an unqualified English language teacher is tolerable only because it provides access to Japanese women as language learners.

Marriage emerged as a new problem for Charisma Man in 2010, when the second compilation booklet of comic strips appeared. One new episode depicts marriage as a 'nightmare,' and an article in The Japan Times (Lewis 2010) announcing the 2010 publication was accompanied by an image of Charisma Man in later life: instead of the young party-goer, we see a doleful Charisma Man carrying a baby, pushing an infant in a stroller, and with his Japanese wife by his side. Has the hyper-heterosexual, single Charisma Man of the 1990s now become, in mid-life, a downcast married man trapped in domesticity? Contrary to these dire 'ball-and-chain' depictions of family life, the accounts of the men in this study suggest that intercultural marriage offers, instead, a way to construct a respectable masculine self, and to cast off potential association with a problematic Charisma Man identity. At the same time, my analysis suggests that the discourses of marriage invoked reflect and reproduce normative assumptions about proper masculinity, and tend to reinforce a spatially, socially and professionally

\footnotetext{
${ }^{6}$ The 'Charisma Man' comics were produced by two Canadian men and originally appeared in The Alien, an Japanese English language magazine, from the mid-1990s to early 2000s. The Charisma Man website (2013) showcases several of the original comic strips and advertises Charisma Man merchandise such as books, T-shirts and condoms (though the latter always appear to be 'sold out').
} 
marginalised position for teachers who do not conform to heteronormative expectations, including those who remain single, or might not identify as heterosexual.

\section{An empirical study of white Western men's narrative accounts}

A series of in-depth, semi-structured interviews with eleven white Australian men form the basis of this paper. These interviews represent part of a larger project (Appleby, forthcoming) that originally set out to investigate how white Western male language teachers experience and negotiate the so-called 'fetish of the white man' in Japan (Kelsky 2001). In the interview context, the comic strip character of 'Charisma Man' served as a trigger for questions about men's experiences in Japan, and the extent of their identification with the Charisma Man stereotype. Although I had not originally set out to examine discourses of marriage and singleness, these emerged as salient features in the men's accounts and were inherent in their constructions of an acceptable masculine self, and a moral geography of Western heterosexuality in Japan. Nine of the eleven interviewees were married (including one de facto relationship) to Japanese women, four of whom had been either a colleague or student. Only two participants, Mike and Lenny, were single. Brief information about the men is given in the table below, but potentially identifying details have been omitted; all names are pseudonyms.

\begin{tabular}{|l|l|l|}
\hline Name & Age (at interview) & Work history in Japan \\
\hline Paul & early 30s & $\begin{array}{l}5 \text { years: teacher in eikaiwa gakkô, then promoted to curriculum } \\
\text { support }\end{array}$ \\
\hline David & late 40s & 11 years: teacher in eikaiwa gakkô, then in tertiary institution \\
\hline Joel & mid 30s & 18 years: teacher in eikaiwa gakkô, then in university \\
\hline Tim & early 50s & 22 years: teacher in vocational college, then in university \\
\hline Eddy & late 30s & 10 years: teacher in eikaiwa gakkô; now seeking work \\
\hline Dan & early 40s & 15 years: teacher in eikaiwa gakkô, then in university \\
\hline Ben* & mid 40s & 10 years: teacher in eikaiwa gakkô, then in high school \\
\hline Luke* & mid 50s & 21 years: teacher in high school; then in university \\
\hline Gus* & mid 30s & 5 years: teacher in eikaiwa gakkô, then promoted to manager \\
\hline Mike* & late 40s & $\begin{array}{l}3 \text { years: teacher in eikaiwa gakkô, then promoted to teacher-trainer } \\
\text { and manager }\end{array}$ \\
\hline Lenny* & mid 40s & 2.5 years: teacher in eikaiwa gakkô; then teacher in high school \\
\hline
\end{tabular}

* had returned to live in Australia at the time of interview.

\# interviewed by a research assistant: an unmarried North American male.

Since the interviews were interactional and co-constructed, the effect of my own subjectivity and presence on the interview process and data analysis requires some explanation. In common with my participants, I am a white Australian, and have worked in Australia and overseas as an English language educator. But as a woman, an academic, and a researcher, I expected I would be viewed by my interlocutors with 
some degree of caution. This expectation was confirmed in an email from one participant, Joel, whose male friends declined to be interviewed on the grounds they suspected I was 'just another comfy shoe wearing gaijin woman with her nose out of joint.' Nevertheless, several participants indicated that they had found the interview afforded a sense of therapeutic relief and catharsis. The interview extracts, and my interpretation, should be read with this in mind.

\section{Discursive analysis of gender and heterosexuality}

My analysis of men's interview accounts draws on Butler's (1990) understandings of gender as a discursive achievement: a repeated, stylised performance within a highly regulated 'heterosexual matrix' - 'that grid of cultural intelligibility through which bodies, genders and desire are naturalized' (Butler 1990: 115). The men's interview accounts are not taken as a reflection of some external or objective 'reality' in, or about, Japan; but instead are taken as discursive practices that produce and project the subject as a particular type of heterosexual masculine self, through highly contextualised talk that entails the 'social positioning of self and other' (Bucholtz \& Hall 2005: 586). As Bucholtz and Hall explain, such positioning can be accomplished linguistically in the interview context by labelling and categorisation of various social actors; by attaching to those categories meanings that invoke particular social and political discourses; and by positioning oneself in relation to those categories and discourses. Positioning the self is broadly achieved by indicating dis/identification with relevant available discourses, and by indicating sameness or difference in relation to various labels and social categories. The discursive analysis adopted in this study highlights how the men's articulation of socially constructed meanings about proper and improper heterosexual masculinity echo heteronormative 'hierarchies of respectability among heterosexuals' (Jackson 2011: 18), and serve to project a particular version of an appropriate masculine self.

The analysis of interview data in the following section is divided into four parts that together seek to demonstrate the ways in which marital status affects the construction of masculinity for the men in this study. The first illustrates the way a commonsense married/single binary was produced and deployed in descriptions of white Australian men in Japan, and identifies the divergent meanings and practices attached to these two categories. The second illustrates how the practices associated with singleness were 
attached to a 'past self,' and how the subsequent transition to marriage was produced as a normative condition of adulthood. The third shows how marriage was aligned with assumptions of maturity, respectability, and professional responsibility. The final section considers the personal and professional marginalisation experienced by those who do not conform to the heteronormative expectations of marriage. In each section, I have selected the extracts that illustrate these emergent themes most clearly.

\section{Producing the married-single binary}

\section{Luke and Gus}

In participants' accounts, representations of acceptable and unacceptable Western heteromasculinity were achieved, to a significant extent, by distinguishing between the behaviours typically associated with married and single men. In Luke's narrative below, a naturalised binary distinction was constructed between these two categories of foreign men in Japan: on the one hand, those who are married, implicitly monogamous, and working to 'look after their families,' and on the other hand, those who are single, promiscuous and the object of critical social scrutiny. Leading into this first extract, Luke had described a group of foreign adults — mostly men — who were studying for a graduate teaching qualification at a Japanese institution with the aim of securing higherlevel jobs within the English language teaching industry in Japan.

\footnotetext{
Luke: A number had come through JET, ${ }^{7}$ or had done a two year stint with say Nova ${ }^{8}$ or something, and had met their wives, married, and they wanted to get a degree, a licence, so they could get a secure job, in the university usually ... or a college, that was their main aim, to look after their families basically.

Ros: So were all the foreign nationals married? To Japanese?

Luke: Oh no ... I would say one in ten it wasn't the case, there was an Israeli couple last year for example, she was Greek descent American-Canadian and he was Israeli; ... there was an American couple ... so ...

Ros: But were they all married? No singles?

Luke: Oh, single males, yeah sure ... and the ones I knew of course they all played the game, you know they were all out diddling themselves stupid basically most of the time ... having sex with girls (laughs), women.

Ros: How did you know that?

Luke: Oh, because their classmates, women, would make comments about them and how they were serial sleeper-ers [with Japanese] women they'd met somewhere.
}

To illustrate his narrative of single men's hypersexuality, Luke then told a story about one young Western male in the program, Brett, who was the subject of gossip amongst

\footnotetext{
${ }^{7}$ JET refers to a government-sponsored program that employs foreigners to teach English in Japanese schools.

${ }^{8}$ Nova was a large Japanese chain of English language schools that went into liquidation in the early 2000 s.
} 
Luke's students and colleagues and was known as 'a tart.' In presenting this story, Luke had switched from an account that characterised all single men as 'diddling themselves stupid' to one that isolates Brett as the only ready example of promiscuity. This slippage demonstrates the way a particular stereotype of singleness can potentially categorise all single men in this context as sexually promiscuous. In continuing this narrative, Luke located promiscuous behaviour in Tokyo's Roppongi bar and nightclub district, a place where foreign men 'go for picking up [Japanese] girls.' The narrative then returned to the contrast provided by married men, presenting Luke with an opportunity to distance himself from the unacceptable behaviour that Brett represents.

\begin{abstract}
Luke: Most of the fellows there were family men, or were committed to living in Japan, yeah. I mean, I was there [in Japan], I was married, you know, [with a] Japanese wife, I was never part of that sort of Roppongi scene, never ... So it was never sort of part of my psyche, I was there to live in the culture and to work, you know. But a lot of guys go there who haven't been [in Japan before], young fellows ... and older too, who have no connections, just, they go there to meet [women] in pubs and stuff.
\end{abstract}

Luke's narrative thus set up a series of distinctions that, first, separated singles and spouses spatially, sexually, socially, and in terms of an internalised disposition; and, second, had significant implications for the constitution of gender politics in social and professional life.

An unbridled performance of heterosexuality amongst single Western men in Japan was an oft-repeated trope in participants' reports and a cornerstone of stigmatised singleness. While Luke's account presented singles' behaviour as relatively innocuous and amusing, most illustrative examples of men who fit this stereotype of 'playing the game' were presented in disparaging terms: participants described them as self-deluded, inauthentic 'Romeos' or 'Lotharios' whose unappealing physical appearance was deemed unworthy of their attractive Japanese girlfriends. Their behaviour was 'ugly,' 'disgusting' and 'exploitative,' they were 'animals,' 'dogs' and 'sleaze-buckets,' and they were frequently referred to as 'people I don't want to hang around [with]' either inside or outside the workplace. These negative assessments of men's sexual behaviour echo the moral panic that had, in earlier decades, seen Japanese women labelled 'yellow cabs' in derogatory media reports that decried their pursuit of Western men (Kelsky 2001). In the men's accounts, an unacceptable Western masculinity was constructed through an excessive concern with sexual pleasure, and cast single men as a category 'at risk of spinning out of control and becoming deviants' (DePaulo \& Morris 2005: 75). 
Oversexed and irresponsible behaviour associated with single men was also linked to a particular type of behaviour in the workplace, where an interest in sleeping with Japanese women was seen by most to be incommensurate with any degree of expertise or interest in teaching. As Gus observed, English language teaching in Japan, particularly in the commercial conversation schools, has been seen as a temporary occupation for those who 'don't know what to do with their lives, so they're going to fill in a year and they just get into whatever comes their way.' Conversation schools, and some lower ranked tertiary institutions, were places that 'are not known for having real teachers'; instead, according to Gus, such organisations relied on a steady stream of unqualified, footloose, young Western men attracted by the lure of easy money and pretty women. Such employees were exemplified in Gus's description of a colleague who 'was basically in Japan for the girls. He wasn't there because he wanted to teach. He certainly wasn't interested in English.'

\section{Normative transitions from singleness to marriage}

\section{Joel and Ben}

For interviewees who had in the past enjoyed a series of casual sexual relationships with Japanese women, including students, singleness was characterised as a transition phase, a temporary state of bodily excess to be superseded by marriage, which was presented as the next life-stage in the development of a 'normal' adult heterosexuality. For Ben and Joel a normative discourse of youthful excess served to explain their past behaviour, and both identified a promiscuous past self that belonged to 'a rite of passage almost, like a phase you go through.' For each, this excess was a phase heightened by the disjuncture between home and abroad.

Joel: I'd gone from rather a sheltered sort of life with my parents in Sydney to one where I'm suddenly, you know, the reins are let loose and I'm 18 and ... if ever I was going to display tendencies of being a Charisma Man, they would have been the conditions: you know, young, stupid, immature and drunk on freedom for the first time.

Given the unflattering discourses of promiscuity that accompanied most descriptions of single Western men, it is not surprising that Joel's account of his younger self as 'stupid' and 'immature' was self-deprecating and apologetic. But Joel also offered several mitigating justifications for this sexual activity as a younger man. The first was that 'most young, working-holiday people are like that, I don't think I'd be an exception,' a justification that reflects and reproduces commonplace understandings not 
only of young men's sex drive (Terry \& Braun 2009; Mooney-Somers \& Ussher 2010) but also of sexual adventure among travellers and expatriates (male and female) away from the constraints of home (see, for example, Appleby, 2010; Hubbard, 2000; Walsh, 2007; Walsh, Shen \& Willis, 2008). A contributing factor, widely mentioned amongst interviewees, was that young single Western men, far from being calculating and predatory, were commodified and, in Joel's words, 'scalped up' (taken as trophies) by calculating Japanese women bent on exploiting naïve single foreign men for sexual or instrumental gains (Piller \& Takahashi 2006). As a consequence, according to several participants, single Western men were often left 'heartbroken,' 'duped' and then 'dumped' by Japanese women who had always intended to marry a Japanese man. This overturning of normative gender hierarchies contributed to the sense of marginalisation conveyed by several men when describing their prior relationships with Japanese women.

In Joel's account, 'growing up' entailed a shift from the confusion of youthful heterosexuality, towards a moral 'centre,' defined around heteronormative ideals of marriage and family life. For Joel, the shift was accompanied by an increasing selfawareness about the positioning of Western men in a new sexual geography:

Joel: When [Western men] first get here, they think it's all wonderful and they're great ... they're desirable and all the rest of it, but most normal people, they soon realise a lot of those relationships aren't going to go anywhere meaningful, and it's a growing up time, change, maturity I suppose, and evolving as a person and being honest with yourself too.

For Ben, too, a transition to marriage was situated within a normative progression of adult heterosexuality. From his point of view, sexual relationships with Japanese women were, in the early years, fun and strictly casual, but as he approached mid-life he started to consider marriage. Ben's account suggested his change of mind was primarily an internalisation of perceived social 'pressure [for] people to get married after 30,' a pressure he depicted as particularly strong in Japan:

Ben: it's funny though, in Japan there is pressure on people to get married after 30, and women in particular. You've heard the Christmas Cake idea? ... The idea, if you get to a certain age ... and you're not married, you were a Christmas Cake, which means: the Japanese, at Christmas time, they buy Christmas cake ... but you put it on the shelf, cos no one wants to eat Christmas cake (laughs) they're too rich. So actually you end up being a Christmas Cake, left on the shelf, and that's it (laughs) so there's pressure on people to get married after that point, and I think for men at the time it was about 30, and I guess it started to cross my mind, yeah perhaps, meet the right person after I'm 30, I'll get married perhaps, but until that time there was no interest at all. And so yeah it just didn't occur to me. 
Ben's account articulates a set of beliefs and expectations - about the natural progression to marriage, and the consequent 'problem' of singleness in mid-life - that are not confined to Japan. A naturalised discourse of evolving maturity combines persistent societal expectations of age-appropriate heterosexual behaviour in both Japanese (Charlebois 2010; Dales 2010; Nemoto 2008) and Western contexts (Reynolds \& Taylor 2004; Terry \& Braun 2009; Reynolds 2008) where, as Sassler (2010: 557) observes, despite 'dramatic changes in the timing and sequencing of relationship stages,' marriage 'increasingly serves as a relationship capstone.' For men such as Ben, an internalised 'social clock' (DePaulo \& Morris 2005: 10) appeared to shape notions of appropriate sexuality and defined an age-graded entry to stable coupledom and marriage as a dominant, normative sign of legitimate adulthood: out of the pubs and into the family home. But for Western men in Japan, marriage could also be deployed to mark a separation from the licentious sexual behaviour associated with single white men, hence separating them from a potentially problematic stereotype.

\section{Social, economic and professional implications of marriage}

David, Dan, Paul and Tim

The men's accounts of married lives demonstrated the 'mature' side of a binary distinction, and articulated the social, economic and professional privileges associated with marital status. Whereas singleness was linked with 'playing around,' and a lack of personal and professional commitment, marriage was presented as a natural choice for men committed to adult responsibility and the rigors of work. In this section, I describe some of the advantages that the men associated with marriage (or even assumed marriage) to a Japanese spouse.

On the whole, the speculation and critique directed towards single men's (and women's) lifestyles stood in stark contrast to both the taken-for-granted ordinariness and respectability of married life, and the relative silence and opacity surrounding marital sexual relations. Although several participants spoke of married men who continued to have sexual relationships with multiple Japanese women, including students, these instances were usually presented as unacceptable aberrations rather than the norm. For the most part, marriage was conflated with commitment and devotion in both personal and professional arenas. Luke's opening narrative, and David's account of 'older guys' below, illustrates this conflation. 
David: I know a couple of guys who work at [a well-known] conversation school, so a similar kind of thing to what Nova used to do. But they're all older guys, you know, they're all married with kids and settled down type of thing. They're pretty diligent about their work and they're interested in teaching well, so they're not really interested in picking up students any more.

Outside the workplace, a significant spatial separation between singles and spouses, illustrated in Luke's opening reference to Roppongi, also supported the presentation of a respectable married identity. For example, Dan recalled his younger, single self 'going out to bars and ... hoping to meet someone,' but 'now that I'm married with three kids ... I don't go out much anymore.' This assertion of retreat into the domestic domain was balanced by a complementary shift into a different set of social practices shared with married friends and colleagues. In particular, Dan asserted that marriage to a Japanese spouse offered a significant entrée into Japanese society by way of integration into a spouse's family-centred cultural life. This opportunity was a key reason given by Dan for choosing a Japanese wife.

\footnotetext{
Dan: That's how you learn about the culture and that's how you learn the language and everything opens up to you ... The best thing about being married to my wife is just, her family, and being part of her family life and being part of obon [Bon Festival] and oshôgatsu [Japanese New Year] and miyamairi [a shrine visit] and going to the temple, and going to the grave, and [when a] big issue comes up, [there's a] family meeting, I'm included in the family and it's all in Japanese and everyone interacts and it's fantastic.
}

In Dan's view, assuming a married identity in Japan offered access to exclusive places and practices, and enabled Dan to position himself as a privileged cultural insider. Marriage to a Japanese spouse also allowed Dan to position himself as a dedicated, responsible citizen, an individual who had chosen self-improvement and hard work to achieve Japanese linguistic, familial and civic integration. Such integration was implicitly either unavailable or unappealing to singles, whom Dan characterised as frivolous, transient sojourners and permanent outsiders in relation to Japanese society and professional life. As such, marriage as a sign of mature masculinity was not only a foil against suspicions about Western promiscuity, but was also, in turn, associated with men taking up a range of socially validated positions in the gendered public world of work (see Connell \& Wood 2005; Roberson \& Suzuki 2003).

Dan: All my friends, pretty much all my friends, except for one, are married to Japanese women, they all speak very good Japanese ... They know things about Japanese culture, they've studied hard, they've worked hard, you know, and they love being here ... They're all my images now, they're the stereotypes of the white male in Japan that I have now. They're fathers, they're husbands, they're respected, and ... a lot of them have tenured positions in universities and they're on committees, ... they're guys who have worked hard to make a place and make a life in very difficult culture. ... And I've worked hard too. So I guess if, you know, I get hit with this 
stereotype that you might just be, you know, 'playing the field' ... of course anyone's going to be a bit offended by that.

This cloak of social and workplace respectability was also articulated by Paul, who said that his publicly celebrated marriage not only freed him from the suspicions that applied to single Western men, but also allowed him a certain amount of interpersonal liberty in his workplace interactions with female students.

Paul: There wasn't any sort of uncertainty, you know, 'oh when he says [that], did he just try to pick me up? or is he sort of checking out women in the class?' like there wasn't anything like that. And when we [got] married the school threw a party for us as well ... So everyone knew I was married and so it was quite easy to talk to people after that. I could be myself, I could make jokes, I could comment ... on people's clothing or hairstyle whatever, 'oh no you're looking really nice today' or 'it's a really cute top' or something like that, and they know that I'm not trying to pick them up because I've got the wedding ring on.

Moreover, several of the men asserted that marriage offered a secure social position specifically recognised by Japanese employers as worthy of economic investment. Paul's marriage was therefore presented as a prerequisite for promotion beyond entrylevel classroom teaching work:

Paul: The company saw me as less transient after [I married]. If you're single or if you've got a girlfriend well big deal, everyone and their dog's got a girlfriend ... But when you get married and you settle down like people see that you're here for the long haul, you're not likely to just get up and leave. And around the same time I did make it known to my bosses ... that I was looking to move up in the company ... I wasn't just going to skip off from them.

According to Tim, a conflation of adult masculinity and marriage was associated with particular professional advantages that relied, in turn, on assumptions about men's favourable position in a gendered domestic hierarchy. Indeed, in Tim's account, opportunities for professional advancement into university teaching were seen as being predicated on Japanese institutional expectations about the men's domestic arrangements.

Tim: If I were to apply for a good position in a Japanese university and I was competing with a woman similar to myself from my own society with identical qualifications, in the Japanese situation I think they'd always give me the nod. The justification is they feel that the male is more likely to slot in with what they want, which is basically you're going to be 16 hours a day if need be to hang around for meetings and you aren't going to rush off because there are domestic attachments.

In the discourses Tim articulates, marriage is the taken-for-granted state for a mature, qualified man, and related assumptions about the division of labour are seen to allow men to participate fully in the workplace. The responsibility for this arrangement is 
projected onto Japanese employers who, in turn, are seen to represent Japanese social norms. In this way, marriage as an interpersonal, domestic relationship has been translated into masculine privilege in the public domain of work. Tim's account reflects widely circulating discourses, supported by statistical evidence, about the gendered division of labour in Japan (see, for example, Lee, Tufis \& Alwin 2010; WEF 2011), ${ }^{9}$ and in Japanese universities where men occupy 83 percent of all academic positions (MEXT 2006). ${ }^{10}$

In sum, the men's identification of workplace privileges attached to martial status, together with the enticements of social and cultural integration, afforded a key to respectable heterosexual masculinity for white Australian men in Japan. As a consequence, these narratives served to cement and reproduce heteronormative ideals. Whereas singleness was constituted in terms of an excessive, embodied sexuality and a frivolous approach to work, marriage enabled identification with a more socially acceptable masculinity: an ideal associated with maturity and professional engagement.

\section{Implications for mid-life singleness}

\section{Luke, David, Lenny and Mike}

The elevated professional status, cultural integration, and images of maturity evoked in the accounts of married men left singles, and particularly older singles, as a problematic category in need of explanation. The effects were demonstrated in Luke's description of Japanese mid-life singles who, by failing to comply with age-appropriate heterosexual expectations, were seen as 'weird': 'If [men are] in their 30s or 40s, and they've never married, there's something wrong ... And if they're in their 30s or 40s and women, there's something wrong.' Luke added that these were 'generalisations' that are 'changing now' with postponement of marriage to a later age, and as a consequence of what Dales calls the 'emergence of a positive discourse of independence for women' (Dales 2010: 2). Nevertheless, the notion of 'wrongness' Luke deploys also reflects the persistence of discourses that regard singleness as a temporary condition, with marriage as the 'normal' end point. Such discourses are evident in Japanese studies showing that the proportion of singles who intend to marry has remained at around 90 percent

\footnotetext{
${ }^{9}$ As Fujimura-Fanselow (2011) points out, despite gains made by Japanese women, particularly in the 1990 s, Japan continues to perform poorly on international measures of women's workplace participation and opportunity, and in measures of political and economic empowerment.

${ }^{10}$ In contrast, men occupy 57 percent of all academic positions in Australian universities (DEEWR 2011).
} 
(Kaneko et al. 2008), and interview studies with single Japanese women confirming that despite expressed desires for independence, 'marriage still occupies central ground in ideals of feminine life-course' (Dales 2010: 10; see also Nemoto 2008; Charlebois 2010) ${ }^{11}$. Mid-life singleness, then, occupies an ambiguous position, and may attract social opprobrium: in Japan, the rise of so-called 'parasite singles' (adult children living at home their with parents) (Yamada 2000) and 'herbivore men' (unassertive men who are indifferent to marriage) (Otagaki 2009) has been blamed for Japan's economic recession and falling birth rate.

For David, mid-life singleness following divorce was described as 'torturous': with his bodily signs of ageing, including baldness, he felt he was not 'guaranteed any privileges' that might otherwise be available to young white Western men as targets of Japanese female desire. Moreover, he eschewed bar-hopping promiscuity, though not on moral grounds, and described himself as 'a real monogamous type.'

David: I was a bit tortured when I got divorced and started looking for a mate again in Japan. Because youth is so highly valued here you know, like it is everywhere I think, mostly that's attributed to being a positive characteristic of women, like youthfulness, youthful beauty. But it's certainly a requirement for the stereotyped Charisma Man type of male, I think. So, you know, when I got divorced and was like 40 and, yeah, not really fitting into the Charisma Man stereotype it was pretty tough, actually.

From David's perspective, because singleness was associated with youth, older Western singles who stayed on in Japan risked being marginalised as ageing social misfits. In particular, men who lingered at the lower echelons of English language teaching, while continuing to enjoy 'a reasonable turnover of [Japanese] girlfriends,' were described by Lenny as being 'stuck in a little bit of a rut ... it seems almost like an extension of their adolescence.' As a result, failure to marry could be seen as a matter of social and professional shame, and Lenny, who returned to Australia unmarried, expressed disappointment that he had remained single despite the purported desirability of white Western men in the eyes of Japanese women.

For men who chose to remain single, stigmatising discourses had to be carefully negotiated. Mike, for example, had described himself as single, sober, serious, and keenly committed to teaching, characteristics that served to deflect potential alignment with a Charisma Man stereotype; however, he believed his unmarried status had

\footnotetext{
11 Similar studies in the USA and UK show that despite changing relationship patterns and increasing tolerance of diversity, singleness in adult life continues to be stigmatised (De Paulo 2006; Reynolds 2008).
} 
hindered his career progression:

\begin{abstract}
Mike: I made pretty good progress with this company, I got to a certain stage, and they said 'you've got to get married, you've gotta get a Japanese girl and marry her.' I thought it was a joke, I was just laughing my head off, but it became quite the thing, it became a sticking point, careerwise I topped out at assistant supervisor ... I couldn't get to the next stage, which was shunin rank, unless I got serious with a Japanese women and I wasn't willing to do that. My bosses ... all had Japanese wives, all the guys, the Westerners that I knew ... To kind of remain in that world, I guess the wife was part of it.
\end{abstract}

Mike presented this expectation of marriage as a turning point. Unlike other men in this study, he resisted the ideal of the transnational, heteronormative couple and constructed instead a Western masculine self based on an agentive and trenchantly independent singleness.

I was into cultural maintenance in a way, in terms of identity I was firmly a Western person, I kind of rejected the idea of learning how to speak, like a baby, in Japanese, it didn't interest me ... I felt it was in my best interest to maintain my identity as an Australian man, rather than a BollywoodJapanese-Western male, a Japanese-speaking Western male.

Mike actively chose not to date Japanese women, and imagined such relationshipsconducted in elementary English or Japanese - as infantilising. He rejected the singles scene located in bars and nightclubs, and constructed an alternative single, mid-life masculinity by drawing not only on discourses of professionalism, but also on discourses of an embodied cultural ideal that relied on refusing the possibility of transnational, transcultural, and translinguistic hybridity and integration (connoted in the phrases 'Bollywood-Japanese-Western male,' and 'Japanese-speaking Western male'). However, these two ideals - of a competent professional self and a culturally distinct single self-were, in Mike's experience, ultimately incompatible: a 'good worker' meant a married worker; commitment to Japan meant marriage to a Japanese woman. And so, unwilling to conform to corporate and cultural demands, Mike 'started to make plans to leave,' and shortly afterwards returned to Australia.

\title{
Conclusion
}

This article has shown the ways in which a group of white Australian men in Japan mobilise meanings attached to singleness and marriage to resist being positioned within negative stereotypes: as promiscuous heterosexuals 'playing the field,' lurking at the margins of professional legitimacy, in a global industry that circulates workers from English-speaking to non-English-speaking countries. The analysis of the men's accounts demonstrates how, in this transnational context, discursive distinctions between 
singleness and marriage affect the construction of a socially and professionally legitimated masculine identity, and enable these Australians abroad to position themselves and others within moral geographies of sexuality. This study is small in scale, and at this stage, the implications I present in relation to white Australian men in Japan are inevitably tentative, specific to English language teaching, and designed to invite (or incite) further research.

\section{Distinctions between married and single masculinity}

The first implication is that the men's distinction between 'single' and 'married' tends to reproduce conservative and institutionally sanctioned discourses to do with the central place of marriage in society. Marriage, as a socially constructed category, provided a safe place for the construction of masculinity, and so supports 'notions of the self [and the other] as an appropriately gendered person' (Wolkomir 2009: 496) for these men. Marriage was discursively associated with maturity, fidelity, family and civic responsibilities, and prestigious integration into Japanese social, cultural, and domestic life. Such discourses suggest the influence of an underlying 'couple culture' (Budgeon 2008) and a taken-for-granted heteronormative ideology of marriage and family (DePaulo \& Morris 2005: 65; Walsh, Shen \& Willis 2008) that persists in many cultures, with potentially damaging effects for those who fall outside these conventions.

\section{Marriage and professional advancement}

The second implication is that the discursive association between marriage and men's readiness for professional responsibility and career advancement tends to reproduce wider structural patterns to do with a gendered division of labour. This is not to say that individual men held gender-conservative views, nor that the individual marriages of the men in this study were organised along gender-conservative lines. (Indeed, in one instance, a participant identified as both an English teacher and, during a temporary lull between contracts, a full-time father and house-husband.) Yet a projected identity as 'married man' afforded the opportunity for interviewees to define themselves as part of a foreign community of teachers who were distinguished by their conscientious and professional work ethic, and also, in turn, present themselves as closely incorporated into patterns of institutional recognition and workplace participation (ongoing contracts, tenure, committee work and so on). In this particular context, marriage to a Japanese spouse is far more likely for Western men than for Western women (Yamamoto 2010; 
MHLW Japan 2010), and Western men are far more likely than Western women to hold a secure English language teaching position in a Japanese university ${ }^{12}$. The perceived alignment between men's marriage and career advancement raises questions about the possibility of 'complicit masculinity' (Connell \& Messerschmidt 2005), whereby white Western men are potential beneficiaries - however unintentionally_of male-dominated employment patterns in Japanese universities.

\section{Producing the abject single}

The third implication arises from the production of a respectable white Western (married) masculinity achieved at the expense of an 'abject' singleness. As Hubbard explains, drawing on Kristeva, abjection prevents 'boundary violation' of the self by mapping 'stereotypical images of repulsion' onto particular social groups (Hubbard 2000: 202). As abject 'others,' Western singles were frequently represented as perpetual outsiders, positioned as transients and failures in both interpersonal and institutional domains. From the perspective of the few men in this study who remained or became single in mid-life, this categorisation was associated with significant barriers in terms of career advancement in Japan, or personal hurdles in meeting suitable partners. For these adult men, then, singleness remained a difficult category, with very few positive representations on which individuals could draw to produce an acceptable masculine self. While research suggests that discourses of celebratory freedom may offer positive alternatives for single women (Reynolds \& Taylor 2004; Reynolds \& Wetherell 2003), for mid-life men in this study, there was little evidence of positive and publicly sanctioned discourses to describe the state of singleness. For single white Western men, and particularly for those in mid-life, discourses of immaturity, age-inappropriateness, professional stagnation and lack of integration into an adult Japanese society and culture remained the most prominent explanations of their uncoupled state.

As Jackson (2011: 18) notes, 'we are only at the beginning of understanding how hierarchies within heterosexuality, among heterosexuals and between heterosexuals and others interconnect in the framing of intimate relationships and wider parameters of

\footnotetext{
${ }^{12}$ Official data on the exact number of non-Japanese men and women employed as English language teachers in Japan is neither collected nor published. However, Hayes (2013) estimates that men occupy 71 percent of foreign English language teacher positions in Japanese universities, a figure replicated in membership of the Japan Association for Language Teaching, where men represent 73 percent of nonJapanese membership. This contrasts with the female dominated membership of equivalent professional organisations in the USA and Australia. Men represent only 36 percent of members in TESOL (International) and 15 percent of NSW (Australia) TESOL.
} 
social life.' By exploring the geography of white Australian heterosexual masculinities, and the persistence of heteronormativity at the confluence of domestic and professional domains, this article has contributed, in a small way, to a better understanding of the particular discursive hierarchies that operate in this complex transnational site.

\section{Acknowledgements}

This research was funded by a grant from the University of Technology, Sydney. My thanks go to Steve Silver for his work as research assistant, and to the men who generously shared their experiences and became part of this research.

\section{Reference List}

Appleby, R. 2010, ELT, Gender and International Development: Myths of Progress in a Neocolonial World. Mulitilingual Matters, Bristol. 2012, 'Desire in Translation: White Masculinity and TESOL,' TESOL Quarterly, doi: 10.1002/tesq.51. (forthcoming), Men and Masculinities in Global English Language Teaching. Palgrave Macmillan, UK.

Bailey, K. 2006, 'Marketing the Eikaiwa Wonderland: Ideology, Akogare, and Gender Alterity in English Conversation School Advertising in Japan,' Environment and Planning D: Society and Space, vol. 24: $105-30$. 2007, “Akogare, Ideology, and "Charisma Man” Mythology: Reflections on Ethnographic Research in English Language Schools in Japan,' Gender, Place and Culture, vol. 15: 585-608.

Bell, D. \& Valentine, G. 1995, 'Introduction: Orientations,' in Mapping Desire: Geographies of Sexualities, (eds) D. Bell \& G. Valentine. Routledge, London:1-27.

Bucholtz, M. \& Hall, K. 2005, 'Identity and Interaction: A Sociocultural Linguistic Approach,' Discourse Studies, vol. 7: 585-614.

Budgeon, S. 2008, 'Couple Culture and the Production of Singleness,' Sexualities, vol. 11: 301-25.

Butler, J. 1990, Gender Trouble: Feminism and the Subversion of Identity. Routledge, New York.

Charisma Man website. 2013, Online, available: http://www.charismaman.com/ [Accessed 20 January 2013].

Charlebois, J. 2010, 'The Discursive Construction of Femininities in the Accounts of Japanese Women,' Discourse Studies, vol. 12: 699-714.

Cho, J. 2012, 'Global Fatigue: Transnational Markets, Linguistic Capital, and Korean-American Male English Teachers in South Korea,' Journal of Sociolinguistics, vol. 16, no. 2: 218-37.

Connell, R. \& Messerschmidt, J. 2005, 'Hegemonic Masculinity: Rethinking the Concept,' Gender \& Society, vol. 19: 829-59.

Connell, R. \& Wood, J. 2005, 'Globalization and Business Masculinities,' Men and Masculinities, vol. 7: 347-64.

Dales, L. 2010, 'Konkatsu and the Ideals of Marriage,' 18th Biennial Conference of the Asian Studies Association of Australia, Adelaide, 5-8 July. Online, available: http://asaa.asn.au/ASAA2010/reviewed papers/Dales-Laura.pdf [Accessed 1 July 2012].

DEEWR (Department of Education, Employment and Workplace Relations Australia) 2011, Staff 2011: Selected Higher Education Statistics Publication. Online, available: http://www.deewr.gov.au/HigherEducation/Publications/HEStatistics/Publications/Pages/Staff.asp $\underline{x}$ [Accessed 19 July 2012].

DePaulo, B. 2006, Singled Out: How Singles are Stereotyped, Stigmatized and Ignored, and Still Live Happily Ever After. St Martins Press, New York.

DePaulo, B. \& Morris, W. 2005, 'Singles in Society and Science' Psychological Inquiry, vol. 16: 57-83.

Farrer, J. 2010, 'A Foreign Adventure's Paradise? Interracial Sexuality and Alien Sexual Capital in Reform Era Shanghai,' Sexualities, vol. 13: 69-95. 2008, 'From "Passports" to "Joint Ventures": Intermarriage Between Chinese Nationals and Western Expatriates Residing in Shanghai,' Asian Studies Review, vol. 32, no. 1: 7-29. 
Fujimura-Fanselow, K. (ed.) 2011, Transforming Japan: How Feminism and Diversity are Making a Difference. The Feminist Press, CUNY, New York.

Gallop, J. 1995, 'The Teacher's Breasts,' in Pedagogy: The Question of Impersonation, (ed.) J. Gallop. Indiana University Press, Bloomington, 79-89.

Hayes, B. E. 2013, 'Hiring Criteria for Japanese University English-Teaching Faculty, in The Native Speaker English Teacher: From Exclusion to Inclusion, (ed.) E. Skutnabb-Kangas. Multilingual Matters, Bristol: 130-44.

Hubbard, P. 2000, 'Desire/Disgust: Mapping the Moral Contours of heterosexuality,' Progress in Human Geography, vol. 24: 191-217.

Ichimoto, T. 2004, 'Ambivalent "Selves" in Transition: A Case Study of Japanese Women Studying in Australian Universities,' Journal of Intercultural Studies, vol. 25, no. 3: 247-69.

Jackson, S. 2011, 'Heterosexual Hierarchies: A Commentary on Class and Sexuality,' Sexualities, vol. 14: $12-20$

Kaneko, R., Sasai, T., Kamano, S., Iwasawa, M., Mita, F. \& Miriizumi, R. 2008, 'Attitudes Toward Marriage and the Family Among Japanese Singles: Overview of the Results of the Thirteenth Japanese National Fertility Survey, Singles,' Japanese Journal of Population, vol. 6, no. 1: 51-75.

Kelly, W. 2008, 'Applying a Critical Metatheoretical Approach to Intercultural Relations: The Case of U.S.-Japanese Communication,' in The Global Intercultural Communication Reader, (eds) M. Asante, Y. Muke, \& J. Yin. Routledge, New York: 263-79.

Kelsky, K. 2001, Women on the Verge: Japanese Women, Western Dreams. Duke University Press, Durham, NC.

Kobayashi, Y. 2002, The Role of Gender in Foreign Language Learning Attitudes: Japanese Female Students' Attitudes Towards English Learning,' Gender and Education, vol. 14, no. 2: 181-97.

Kubota, R. 2008, 'A Critical Glance at Romance, Gender, and Language Teaching,' Essential Teacher, vol. 5 , no. $3: 28-30$.

2011, 'Learning a Foreign Language and Leisure and Consumption: Enjoyment, Desire, and the Business Of Eikaiwa,' International Journal of Bilingual Education and Bilingualism, vol. 14, no. 4: 473-88.

Lan, P-C. 2011, 'White Privilege, Language Capital and Cultural Ghettoisation: Western High-Skilled Migrants in Taiwan,' Journal of Ethnic and Migration Studies, vol. 37, no.10: 1669-93.

Lee, K. S. Tufis, P. A. \& Alwin, D. F. 2010, 'Separate Spheres or Increasing Equality? Changing Gender Beliefs in Postwar Japan,' Journal of Marriage and Family, vol. 72: 184-201.

Lewis, C. 2010, 'One More Time-With Charisma,' The Japan Times Online, 13 July. Online, available: http://search.japantimes.co.jp/cgi-bin/fl20100713zg.html [Accessed 30 July 2010].

Ling, L. H. M. 1999, 'Sex Machine: Global Hypermasculinity and Images of the Asian Moman in Modernity,' Positions, vol. 7: 277-306.

Ma, K. 1996, The Modern Madame Butterfly: Fantasy and Reality in Japanese Cross-Cultural Relationships. Charles E. Tuttle, Rutland.

McDowell, L. 2008, 'Thinking Through Work: Complex Inequalities, Constructions of Difference and Trans-National Migrants,' Progress in Human Geography, vol. 32: 491-507.

MEXT (Ministry of Education, Culture, Sports, Science and Technology Japan) 2006, Statistical Abstract 2006 Edition 1.11 University and Junior College. Online, available: http://www.mext.go.jp/english/statistics/1302965.htm [Accessed 19 July 2012].

MHLW (Ministry of Health, Labour and Welfare Japan) 2010, Vital Statistics of Japan: Trends in Marriage by Nationality of Bride and Groom. Online, available: http://www.mhlw.go.jp/english/ (Accessed 1 July 2012).

Mooney-Somers, J. \& Ussher, J. 2010, 'Sex as Commodity: Single and Partnered Men's Subjectification as Heterosexual Men,' Men and Masculinities, vol. 12: 353-73.

Nemoto, K. 2008, 'Postponed Marriage: Exploring Women's Views of Matrimony and Work in Japan,' Gender and Society, vol. 22: 219-37.

Ono, H. \& Piper, N. 2004, 'Japanese Women Studying Abroad, the Case of the United States,'Women's Studies International Forum, vol. 27: 101-18.

Otagaki, Y. 2009, 'Japan's “Herbivore Men” Shun Corporate Life, Sex,' Reuters, 27 July. Online, available: http://www.reuters.com/article/2009/07/27/us-japan-herbivoresidUSTRE56Q0C220090727 [Accessed 21 July 2012].

Philo, C. 2005, 'Sex, Life, Death, Geography: Fragmentary Remarks Inspired by Foucault's Population Geographies,' Population Space \& Place, vol. 11: 325-33.

Piller, I. \& Takahashi, K. 2006, 'A Passion for English: Desire and the Language Market,' in Bilingual Minds: Emotional Experience, Expression and Representation, (ed.) A. Pavlenko. Multilingual Matters, Clevedon: 59-83. 
Reynolds, J. 2008, The Single Woman: A Discursive Investigation. Routledge, New York.

Reynolds, J. \& Taylor, S. 2004, 'Narrating Singleness: Life Stories and Deficit Identities,' Narrative Inquiry, vol. 25: 197-215.

Reynolds, J. \& Wetherell, M. 2003, 'The Discursive Climate of Singleness: The Consequences for Women's Negotiation of Single Identity,' Feminism and Psychology, vol. 13: 489-510.

Roberson, J. E. \& Suzuki, N. (eds) 2003, Men and Masculinities in Contemporary Japan: Dislocating the Salaryman Doxa. RoutledgeCurzon, London.

Robinson, K. 2007, 'Marriage Migration, Gender Transformations, and Family Values in the "Global Ecumene",' Gender, Place \& Culture, vol. 14: 483-97.

Rodney, L. \& Garscadden, N. 2002, Charisma Man: The Complete Collection. AKNG Press, Tokyo. 2010, Charisma Man 1998-2010: The Even More Complete Collection. AKNG Press, Tokyo.

Said, E. 1978, Orientalism. Routledge, London.

Sassler, S. 2010, 'Partnering Across the Life Course: Sex, Relationships, and Mate Selection,' Journal of Marriage and Family, vol. 72: 557-75.

Seargeant, P. 2009, The Idea Of English in Japan: Ideology and the Evolution of a Global Language. Multilingual Matters, Boston.

Stanley, P. 2012, 'Superheroes in Shanghai: Constructing Transnational Western Men's Identities,' Gender, Place and Culture, vol. 19, no. 2: 213-31.

Stoler, A.L. 1995, Race and the Education of Desire: Foucault's History of Sexuality and the Colonial Order of Things. Duke University Press, Durham, NC.

Terry, G. \& Braun, V. 2009, 'When I was a Bastard: Constructions of Maturity in Men's Accounts of Masculinity,' Journal of Gender Studies, vol. 18: 165-78.

Valentine, G. 1997, 'Ode to a geography Teacher: Sexuality and the Classroom,' Journal of Geography in Higher Education, vol. 21: 417-24.

Walsh, K. 2007, “'It Got Very Debauched, Very Dubai!” Heterosexual Intimacy Amongst Single British Expatriates,' Social \& Cultural Geography, vol. 8, no. 4: 507-533.

Walsh, K., Shen, H. \& Willis, K. 2008, 'Heterosexuality and Migration in Asia,' Gender, Place \& Culture, vol. 15: 575-79.

WEF (World Economic Forum) 2011, The Global Gender Gap Report, Geneva, Switzerland. Online, available: http://www.weforum.org/reports/global-gender-gap-report-2011 [Accessed 14 July 2012].

Wolkomir, M. 2009, 'Making Heteronormative Reconciliations: The Story of Romantic Love, Sexuality, and Gender in Mixed-Orientation Marriages,' Gender \& Society, vol. 23: 494-519.

Yamada, M. 2000, 'The Growing Crop of Spoiled Singles,' Japan Echo, June: 49-53.

Yamamoto, B. A. 2010, 'International Marriage in Japan: An Exploration of Intimacy, Family and Parenthood,' Paper presented at the $18^{\text {th }}$ Biennial Conference of the Asian Studies Association of Australia, Adelaide, 5-8 July. 